\title{
REVIEW
}

\section{Role of VEGF-A in Pancreatic Beta Cells}

\author{
HIROTAKA WATADA \\ Department of Medicine, Metabolism and Endocrinology, Faculty of Medicine, Juntendo University School of Medicine, Tokyo \\ 113-8421, Japan
}

\begin{abstract}
The islet contains a dense vascular structure of several features. The expression of vascular endothelial growth factor (VEGF)-A in beta cells is indispensable for the formation of this structure. Thus, the beta-cell-specific VEGF-Adeficient mouse (RIP-Cre:Vegf ${ }^{f / f}$ ) is useful for studying the role of the islet vasculature on the function of islets and regulation of beta-cell mass. Studies using RIP-Cre:Vegf $\mathrm{f}^{\mathrm{t} / \mathrm{l}}$ mice revealed that defects in the normal vascular structure are associated with abnormal insulin secretion and concluded that the islet vascular system is essential for normal insulin secretion into the blood stream. On the other hand, whereas the endothelial cells might be involved in regulation of islet mass and the mouse model of diabetes shows that the number of endothelial cells correlate with the islet mass, RIPCre: $\mathrm{Vegf}^{\mathrm{ft} / \mathrm{fl}}$ mice show almost normal response of islet expansion in the presence of insulin resistance. On the other hand, whereas bone marrow transplantation induces islet expansion in wildtype mice, it does not induce the proper expansion of beta-cell mass in RIP-Cre:Vegf ${ }^{\mathrm{f} / \mathrm{fl}}$ mice. These data indicate that the roles of VEGF-A and islet vasculature on the regulation of beta-cell mass depends on the stimulus for the islets.
\end{abstract}

Key words: VEGF-A, Islet, Endothelial cells, Beta-cell mass

THE TWO MAJOR ABNORMALITIES in type 2 diabetes mellitus are the failure of beta-cell function and deterioration of systemic insulin sensitivity. While insulin resistance is an abnormality common to almost all type 2 diabetes mellitus, insulin resistance is also observed in many subjects who never develop type 2 diabetes mellitus. Thus, insulin resistance cannot be a specific determinant of the onset of type 2 diabetes. In the presence of insulin resistance, normal beta cells can increase insulin secretion to amounts sufficient to maintain glucose homeostasis as a compensatory response. On the other hand, in type 2 diabetes or subjects who will progress to type 2 diabetes mellitus in the future, beta cells fail to adapt to systemic insulin resistance, leading to hyperglycemia. In this regard, the onset of type 2 diabetes is determined by the failure of the compensatory response of beta cells for insulin resistance. Furthermore, the progression of beta-cell dysfunction is a common event in

Received Feb. 3, 2010; Accepted Feb. 4, 2010 as K10E-035 Released online in J-STAGE as advance publication Feb.24, 2010 Correspondence to: Hirotaka WATADA, Department of Medicine, Metabolism and Endocrinology, School of Medicine, Juntendo University Faculty of Medicine 2-1-1 Hongo, Bunkyo-ku, Tokyo 113-8421, Japan. e-mail: hwatada@juntendo.ac.jp most people with established type 2 diabetes mellitus and is associated with worsening glycemic control. Thus, type 2 diabetes should be regarded as a disease of "pancreatic beta-cell failure."

One of the earliest signs of beta-cell failure in the natural history of type 2 diabetes is a specific loss of glucose-induced insulin secretion, whereas secretion in response to other secretagogues is maintained at the stage. At that situation, a decrease of first phase insulin release, and delayed insulin secretion in response to oral glucose load is typically observed. Another defect is decreased beta-cell mass. Pathological studies demonstrated that in patients with type 2 diabetes mellitus, the islet size is small and the number of insulinproducing cells is low, and that subjects with impaired glucose tolerance already show significant decrease of islet mass, similar to patients with type 2 diabetes mellitus. In addition, islet mass has been shown to correlate with fasting plasma glucose levels. These studies suggest that the reduction of beta-cell mass occurs earlier than expected and that the decrease in beta-cell mass as well as dysfunction of each islet are the main features of beta-cell failure in type 2 diabetes.

Pancreatic islets are highly vascularized tissue and exhibits special features. The formation of this struc- 
A

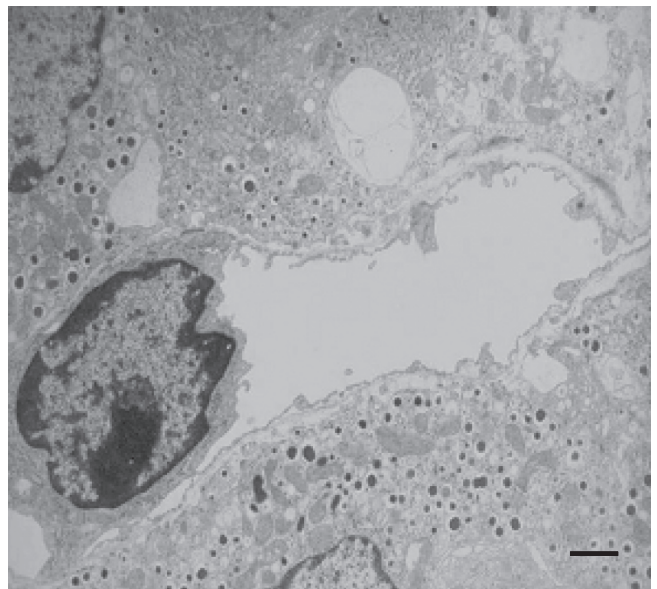

B

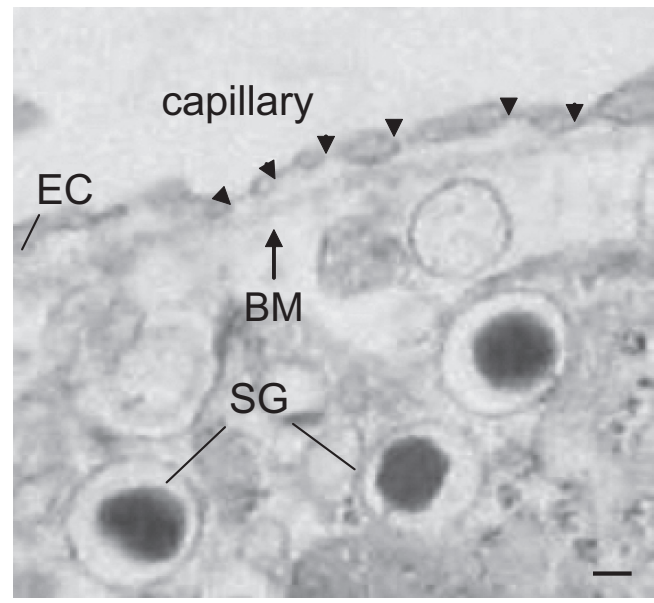

Fig. 1. Vascular structure of islets.

Electron microscopy showing capillaries surrounded by pancreatic $\beta$ cells. Scale bars $=0.25 \mu \mathrm{m}(\mathrm{A})$ and $50 \mathrm{~nm}$ (B). Arrowheads point to fenestrae. EC, endothelial cell; SG, secretory granule; BM, basement membrane.

ture depends on the expression of VEGF-A in beta cells. VEGF-A is regarded as an important factor for normal beta-cell function. However, the causal relation between normal vascular system and beta-cell function and mass was not clear until the establishment of mice with beta-cell-specific deletion of VEGF-A ( RIP-Cre:Vegf ${ }^{\mathrm{A} / \mathrm{fl}}$ ). This review summarizes the current knowledge of the role of VEGF-A in islet function based on studies on RIP-Cre:Vegf ${ }^{\mathrm{f} / \mathrm{fl}}$.

\section{VEGF-A is Indispensable for the Formation of Vasculature in Islets}

Insulin is secreted from pancreatic islets by various physiological secretagogues and an adequate and precise pattern of insulin secretion is essential for maintenance of euglycemia. Islet vascularization exhibits specific features compared with the exocrine pancreas. The islet capillary network is about five times denser than that of the exocrine tissue and the microvasculature of pancreatic islets consists of thin fenestrated endothelial cells separated from beta cells by the basement membrane [1,2] (Fig. 1). The islet microvasculature has a unique relationship with beta cells, which are polarised with one domain facing an arterial capillary while the other faces a venous capillary [3]. In addition, islets contain canaliculi located between the lateral faces of beta cells. These canaliculi contain many microvilli with high production of GLUT2 [4]. The formation of this featured vascular system requires the participation of VEGF-A that is a key regu- lator of vasculogenesis, angiogenesis, vascular permeability, and endothelial fenestration formation [7-9].

In the pancreas, VEGF-A is highly produced in islets compared with exocrine cells $[5,6]$. The importance of VEGF-A has been shown by the studies of RIP-Cre:Vegf ${ }^{\mathrm{f} / \mathrm{fl}}$ mice. The RIP-Cre:Vegf ${ }^{\mathrm{f} / \mathrm{fl}}$ mice show reduced vascularization with reduced fenestration in islets $[5,11,12]$. In addition, pancreatic-specific deletion of VEGF-A (PDX1-Cre:Vegf $f^{\mathrm{fl} / \mathrm{fl}}$ ) also results in reduced vascularization and fenestration of islet capillaries [13]. Although other family members of VEGF are expressed in beta cells [5], these results clearly indicate that VEGF-A in the pancreas plays a nonredundant role in the formation of dense fenestrated capillaries in the islets.

VEGF-A binds to VEGF receptor (VEGFR)-1 [also known as FMS-like tyrosine kinase 1 (Flt1)] and VEGFR-2 [also known as kinase insert domain protein receptor $(\mathrm{Kdr})]$, the expression of which is largely restricted to endothelial cells. On the other hand, other family members also bind to VEGFR-1 and VEGFR-2. Placental growth factor and VEGF-B can bind to VEGFR-1, while VEGF-C and VEGF-D can bind to VEGFR-2 (Fig. 2) [10]. $\alpha$ Previous study investigated the effect of AG-013736, which inhibits VEGF receptor tyrosine kinases, including VEGFR-1, VEGFR-2, soluble VEGFR-1 (which inhibits the ligand binding to VEGFR-1) and soluble VEGFR-2 (which inhibits the ligand binding to VEGFR-2), on microvasculature in several tissues [6]. The investigators demonstrated that administration of AG-013736 


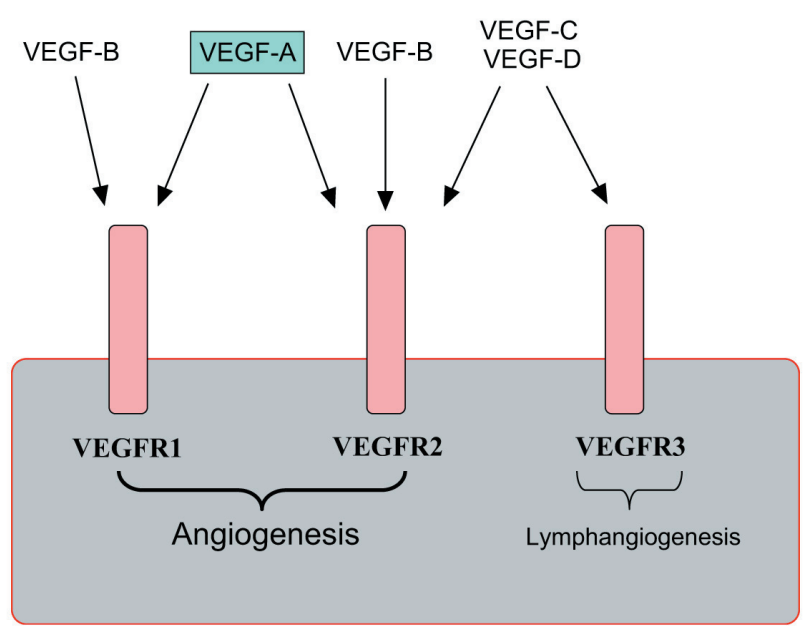

Fig. 2. Members of the VEGF family and their receptors. VEGF family members bind to the corresponding receptors.

resulted in $60 \%$ reduction in intra-islet microvasculature, that soluble VEGFR-1 results in 54\% decrease in intra-islet microvasculature, and that soluble VEGFR-2 results in 14\% decrease in intra-islet vasculature. These findings suggest that VEGF-A plays an important role in intra-islet vascular structure by binding to VEGFR-1, although other factors could partly substitute the effect of VEGF-A.

\section{Effect of Featured Vascular Structure on Insulin Secretion}

The RIP-Cre:Vegf ${ }^{\mathrm{f} / \mathrm{fl}}$ mouse is a useful model to investigate the role of vascular structure on beta-cell function because it shows reduced number of islet endothelial cells with little fenestration and increased caveolae-like structures. Our analysis of beta-cell function in these mice showed normal beta-cell mass, and normal amount and distribution of alpha cells in islets. Apart from abnormal islet endothelial cells, obvious morphological abnormalities were not observed in islets of RIP-Cre; $\mathrm{Vegf}^{\mathrm{f} / \mathrm{fl}}$ mice.

With regard to the capability of secretion of insulin, these mice show modest glucose intolerance with impaired glucose-stimulated insulin secretion as judged by glucose tolerance test in vivo. To investigate whether this feature is caused by failure of betacell function or failure of the vascular structure, we measured insulin secretion from isolated islets, because insulin secretagogues can directly infiltrate beta cells and the ability of insulin secretion can be evalu- ated by measuring insulin levels in the culture medium, in this system. In contrast to beta-cell function in RIP-Cre:Vegf ${ }^{\mathrm{fl} / \mathrm{fl}}$ mice in vivo, glucose- and $\mathrm{KCl}$ stimulated levels of secreted insulin from isolated islets of RIP-Cre:Vegf ${ }^{\text {fl/fl }}$ mice were higher than from control mice. In addition, these mice showed reductions in both tolbutamide-stimulated insulin secretion and arginine-stimulated glucagon secretion. Thus, these results suggest that normal islet vascular system is indispensable for normal hormone release from islets into blood stream, however, the abnormality of vascular structure does not result in substantial failure of beta-cell function by itself [12].

\section{Role of the Featured Vascular Structure on Increased Islet Mass Induced by Insulin Resistance}

While many signal transduction pathways affect beta-cell growth, islet angiogenesis is also critical for normal islet formation during embryonic and early postnatal development $[13,14]$. Lammert et al. have proposed a model of the relation between vascular endothelial cells and islet development [15]. Vascular endothelial cells first stimulate islet development from pancreatic epithelium. After then, islet cells stimulate vascular endothelial cells to form a branching network of capillaries in the growing islet and vascular endothelial cells secrete mitogens, such as hepatocyte growth factor, which seem to stimulate beta-cell replication.

After the developmental stage of islets, an increase in islet mass is viewed as an important adaptive reaction to insulin resistance [16]. This phenomenon is generally observed in high fat-loaded mice or genetic mice models of insulin resistance before the onset of overt hyperglycemia [17]. Hyperglycemia seen in rats chronically infused with glucose or partially pancreatomized rats, also stimulate increases in functional beta-cell mass $[18,19]$. On the other hand, there is ample evidence to suggest that tumor growth is dependent on angiogenesis [20,21]. With regard to the islet tumor, a mouse model of islet tumor reported that VEGF-A expression in beta cells correlated with tumor mass [5]. Moreover, previous studies indicated that the mass of normal adipose tissue depends on the rate of angiogenesis [22]. These data suggest a tight relation between the number of islet endothelial cells and beta-cell mass.

Regarding the expansion of beta-cell mass in adult, 
recent data indicate that insulin resistance-induced islet hyperplasia is associated with an increase in the number of endothelial cells. In some rodent models prone to diabetes, the number of endothelial cells decreases in parallel with islet failure [24]. In terms of molecular link between islet mass and vascular system, Nikolova et al. [23] indicated that laminins, a group of vascular basement proteins generated by islet endothelial cells, are essential for the proliferation of beta cells through beta 1-integrin. However, the causal relation between the increase in vascular system and beta-cell mass had not been clear.

To investigate the role of islet angiogenesis on the expansion of beta-cell mass in response to insulin resistance, we investigated the effect of high-fat diet on islet mass in RIP-Cre:Vegf ${ }^{\mathrm{f} / \mathrm{fl}}$ mice. High-fat diet augmented endothelial cell area in control normal mice, but no such increase in beta-cell mass was observed in RIP-Cre:Vegf ${ }^{\mathrm{A} / \mathrm{f}}$ mice. In this condition, islet mass is increased in both strains of mice by high-fat diet. The increase was more pronounced in the RIP-Cre:Vegf ${ }^{\mathrm{A} / \mathrm{fl}}$ compared to control mice. These results indicate that normal vascularization in islets is dispensable for expansion of beta-cell mass in response to high-fat-diet induced insulin resistance [25].

\section{Role of Featured Vascular Structure on Increased Islet Mass Induced by Bone Marrow Transplantation}

Several studies have indicated that bone marrow (BM)-derived cells have the capacity to differentiate into various cell types through a process termed transdifferentiation [26-33]. However, these data are controversial, because several other studies reported that these cells fail to show such transdifferentiation [34-39]. With regard to pancreatic beta cells, a previous study showed that BM-derived cells can directly transdifferentiate into beta cells [40]. On the other hand, other groups including ours showed that very few or no BM-derived cells transdifferentiate into insulin-positive cells in islets [41-43]. While the difference in the aforementioned results might emanate from different procedures used for tracing transplanted BM-derived cells, recently, Taneera et al. [44] systematically compared various approaches that promote transdifferentiation of BM cells to beta cells and demonstrated that BM-derived cells engraft efficiently in the pancreas but adopt almost exclusively a he- matopoietic cell fate.

Apart from the issue of cell fate of BM-derived cells, recent studies have suggested that BM transplantation (BMT) promotes the expansion of beta-cell mass and results in improvement of hyperglycemia in streptozotocin (STZ)-induced diabetic mice [45, 46]. In addition, other studies demonstrated that BMT improves hyperglycemia in other types of diabetic animals; including E2f1/E2f2 mutant mice [47], and KKAy mice [48].

We have also investigated the effect of BMT on beta-cell mass in STZ-induced diabetic mice. After induction of diabetes, we performed BMT in one group of mice and compared the relative beta-cell mass at 2 days and 8 weeks after BMT. Interestingly, BMT improved glucose tolerance with augmentation of insulin secretion. At 8 weeks after STZ treatment, BMT resulted in a significant increase of relative beta-cell mass, whereas a significant decrease of relative betacell mass was observed in mice that did not receive BMT. In addition, a larger number of Ki-67 positive cells were noted in BMT mice. In this situation, BMT increased the number of endothelial cells in islets, although BM cells do not seem to provide the bulk of accumulated endothelial cells in islets. Such BMTassociated increase in endothelial cells may play a role in the expansion of beta-cell mass.

Thus, to investigate the role of vascular structure in islets on the increase in beta-cell mass by BMT, we analyzed pancreatic islets of RIP-Cre:Vegf $f^{\mathrm{f} / \mathrm{f}}$ mice and control mice after BMT. The results showed that BMT did not increase vascularization or beta-cell mass in STZ-treated RIP-Cre:Vegf ${ }^{\mathrm{fl} / \mathrm{f}}$ mice, suggesting that VEGF-A and/or the resultant increased number of endothelial cells are essential at least for BMTinduced increase of beta-cell mass [49].

\section{How do We Interpret Islet Function in RIP-Cre:Vegf ${ }^{\mathrm{f} / \mathrm{fl}}$ Mice?}

The islets contain dense vascular structure and the data obtained from studies on RIP-Cre:Vegf ${ }^{\mathrm{A} / \mathrm{fl}}$ mice indicate that dysfunction of vascular structure is associated with deterioration of insulin secretion $[11,12]$. With regard to islet cell mass, although diabetic mice show that endothelial cells regulate islet mass and that endothelial cell number correlate with islet mass [24], the reduced number of endothelial cells does not change islet expansion by insulin resistance [25]. 
This result does not necessarily suggest that endothelial cells are not important for the maintenance of islets mass. Because growth factors such as HGF secreted by endothelial cells have a growth-promoting effect on islets, it is also possible that the islets of RIP$\mathrm{Cre}: \mathrm{Vegf} \mathrm{fl}^{\mathrm{f} / \mathrm{l}}$ mice could increase the expression of other factors that promote islet growth to compensate for the defect in endothelial cells. Whereas BMT induced increase in beta-cell mass is regarded as unusual situation, under this situation VEGF-A and islet vascular structure are proved to be important for the expansion of beta-cell mass. It is possible that the factors that compensate for the defect of endothelial cells may not be up-regulated in this situation (Fig. 3). The identification of such factors could be important to our understanding of the relation between islet vascular system and islet mass.

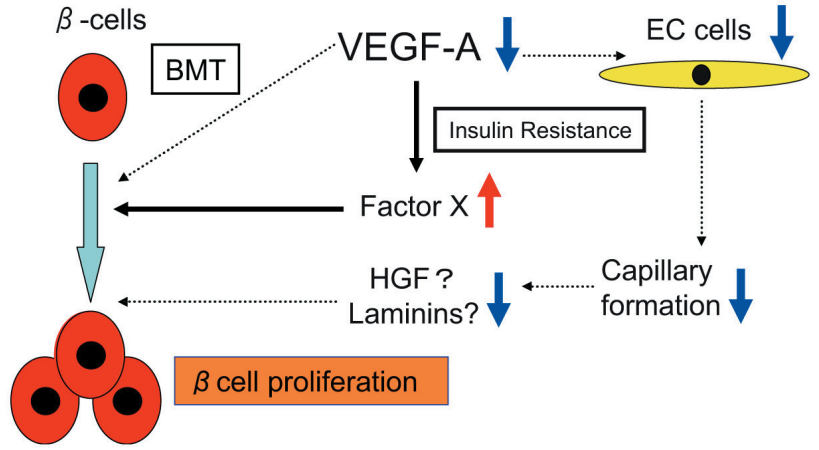

Fig.3. Hypothetical scheme for the role of VEGF-A on beta cell expansion.

BMT, bone marrow transplantation. Decreased expression of VEGF-A in beta cells reduced endothelial cell number, thus results in the reduced expression of essential factors for islet expansion. Under the condition of insulin resistance, an unknown factor (factor X) may be upregulated and compensate for the endothelial cell derived factors. On the other hand, in case with BMT, this compensatory mechanism may not work.

\section{References}

1. Konstantinova I, Lammert E (2004). Microvascular development: learning from pancreatic islets. Bioessays 26: 1069-1075.

2. Henderson JR, Moss MC (1985). A morphometric study of the endocrine and exocrine capillaries of the pancreas. QJ Exp Physiol 70: 347-356.

3. Bonner-Weir S (1988). Morphological evidence for pancreatic polarity of beta-cell within islets of Langerhans. Diabetes 37: 616-621.

4. Orci L, Thorens B, Ravazzola M, Lodish HF (1989). Localization of the pancreatic beta cell glucose transporter to specific plasma membrane domains. Science 245: 295-297.

5. Inoue M, Hager JH, Ferrara N, Gerber HP, Hanahan D (2002). VEGF-A has a critical, nonredundant role in angiogenic switching and pancreatic beta cell carcinogenesis. Cancer Cell 1: 193-202.

6. Kamba T, Tam BY, Hashizume H, Haskell A, Sennino B, Mancuso MR, Norberg SM, O'Brien SM, Davis RB, Gowen LC, Anderson KD, Thurston G, Joho S, Springer ML, Kuo CJ, McDonald DM (2006). VEGFdependent plasticity of fenestrated capillaries in the normal adult microvasculature. Am J Physiol Heart Circ Physiol 290: H560-576.

7. Ferrara N, Gerber HP, LeCouter J (2003). The biology of VEGF and its receptors. Nat Med 9: 669-676.

8. Esser S, Wolburg K, Wolburg H, Breier G, Kurzchalia T, Risau W (1998). Vascular endothelial growth factor induces endothelial fenestrations in vitro. $J$ Cell Biol 140: $947-959$.

9. Issbrucker K, Marti HH, Hippenstiel S, Springmann
G, Voswinckel R, Gaumann A, Breier G, Drexler HC, Suttorp N, Clauss M (2003). p38 MAP kinase--a molecular switch between VEGF-induced angiogenesis and vascular hyperpermeability. FASEB J 17: 262-264.

10. Shibuya M, Ito N, Claesson-Welsh L (1999). Structure and function of vascular endothelial growth factor receptor-1 and -2. Curr Top Microbiol Immunol 237: 59-83.

11. Brissova M, Shostak A, Shiota M, Wiebe PO, Poffenberger G, Kantz J, Chen Z, Carr C, Jerome WG, Chen J, Baldwin HS, Nicholson W, Bader DM, Jetton T, Gannon M, Powers AC (2006). Pancreatic islet production of vascular endothelial growth factor--a is essential for islet vascularization, revascularization, and function. Diabetes 55: 2974-2985.

12. Iwashita N, Uchida T, Choi JB, Azuma K, Ogihara T, Ferrara N, Gerber H, Kawamori R, Inoue M, Watada H (2007). Impaired insulin secretion in vivo but enhanced insulin secretion from isolated islets in pancreatic beta cell-specific vascular endothelial growth factor-A knock-out mice. Diabetologia 50: 380-389.

13. Lammert E, Gu G, McLaughlin M, Brown D, Brekken R, Murtaugh LC, Gerber HP, Ferrara N, Melton DA (2003). Role of VEGF-A in vascularization of pancreatic islets. Curr Biol 13: 1070-1074.

14. Lammert E, Cleaver O, Melton D (2001). Induction of pancreatic differentiation by signals from blood vessels. Science 294: 564-567.

15. Ballian N, Hu M, Liu SH, Brunicardi FC (2007). Proliferation, hyperplasia, neogenesis, and neoplasia in the islets of Langerhans. Pancreas 35: 199-206.

16. Bonner-Weir S (1994). Regulation of pancreatic beta- 
cell mass in vivo. Recent Prog Horm Res 49: 91-104.

17. Kahn SE (2001). Clinical review 135: The importance of beta-cell failure in the development and progression of type 2 diabetes. J Clin Endocrinol Metab 86: 40474058.

18. Bonner-Weir S, Deery D, Leahy JL, Weir GC (1989). Compensatory growth of pancreatic beta-cells in adult rats after short-term glucose infusion. Diabetes 38: 4953.

19. Bonner-Weir S, Trent DF, Weir GC (1983). Partial pancreatectomy in the rat and subsequent defect in glucose-induced insulin release. J Clin Invest 71: 15441553.

20. Rak J, Filmus J, Kerbel RS (1996). Reciprocal paracrine interactions between tumour cells and endothelial cells: the 'angiogenesis progression' hypothesis. Eur $J$ Cancer 32A: 2438-2450.

21. Hanahan D, Folkman J (1996). Patterns and emerging mechanisms of the angiogenic switch during tumorigenesis. Cell 86: 353-364.

22. Rupnick MA, Panigrahy D, Zhang CY, Dallabrida SM, Lowell BB, Langer R, Folkman MJ (2002). Adipose tissue mass can be regulated through the vasculature. Proc Natl Acad Sci US A 99: 10730-10735.

23. Nikolova G, Jabs N, Konstantinova I, Domogatskaya A, Tryggvason K, Sorokin L, Fassler R, Gu G, Gerber HP, Ferrara N, Melton DA, Lammert E (2006). The vascular basement membrane: a niche for insulin gene expression and beta cell proliferation. Dev Cell 10: 397-405.

24. Li X, Zhang L, Meshinchi S, Dias-Leme C, Raffin D, Johnson JD, Treutelaar MK, Burant CF (2006). Islet microvasculature in islet hyperplasia and failure in a model of type 2 diabetes. Diabetes 55: 2965-2973.

25. Toyofuku Y, Uchida T, Nakayama S, Hirose T, Kawamori R, Fujitani Y, Inoue M, Watada H (2009). Normal islet vascularization is dispensable for expansion of beta-cell mass in response to high-fat diet induced insulin resistance. Biochem Biophys Res Commun 383: 303-307.

26. Bjornson CR, Rietze RL, Reynolds BA, Magli MC, Vescovi AL (1999). Turning brain into blood: a hematopoietic fate adopted by adult neural stem cells in vivo. Science 283: 534-537.

27. Brazelton TR, Rossi FM, Keshet GI, Blau HM (2000). From marrow to brain: expression of neuronal phenotypes in adult mice. Science 290: 1775-1779.

28. Gussoni E, Soneoka Y, Strickland CD, Buzney EA, Khan MK, Flint AF, Kunkel LM, Mulligan RC (1999). Dystrophin expression in the mdx mouse restored by stem cell transplantation. Nature 401: 390-394.

29. Jackson KA, Majka SM, Wang H, Pocius J, Hartley CJ, Majesky MW, Entman ML, Michael LH, Hirschi KK, Goodell MA (2001). Regeneration of ischemic cardiac muscle and vascular endothelium by adult stem cells. $J$ Clin Invest 107: 1395-1402.
30. Lagasse E, Connors H, Al-Dhalimy M, Reitsma M, Dohse M, Osborne L, Wang X, Finegold M, Weissman IL, Grompe M (2000). Purified hematopoietic stem cells can differentiate into hepatocytes in vivo. Nat Med 6: 1229-1234.

31. Mezey E, Chandross KJ, Harta G, Maki RA, McKercher SR (2000). Turning blood into brain: cells bearing neuronal antigens generated in vivo from bone marrow. Science 290: 1779-1782.

32. Orlic D, Kajstura J, Chimenti S, Jakoniuk I, Anderson SM, Li B, Pickel J, McKay R, Nadal-Ginard B, Bodine DM, Leri A, Anversa P (2001). Bone marrow cells regenerate infarcted myocardium. Nature 410: 701-705.

33. Petersen BE, Bowen WC, Patrene KD, Mars WM, Sullivan AK, Murase N, Boggs SS, Greenberger JS, Goff JP (1999). Bone marrow as a potential source of hepatic oval cells. Science 284: 1168-1170.

34. Wagers AJ, Sherwood RI, Christensen JL, Weissman IL (2002). Little evidence for developmental plasticity of adult hematopoietic stem cells. Science 297: 22562259.

35. Castro RF, Jackson KA, Goodell MA, Robertson CS, Liu H, Shine HD (2002). Failure of bone marrow cells to transdifferentiate into neural cells in vivo. Science 297: 1299.

36. McKinney-Freeman SL, Jackson KA, Camargo FD, Ferrari G, Mavilio F, Goodell MA (2002). Musclederived hematopoietic stem cells are hematopoietic in origin. Proc Natl Acad Sci U S A 99: 1341-1346.

37. Nygren JM, Jovinge S, Breitbach M, Sawen P, Roll W, Hescheler J, Taneera J, Fleischmann BK, Jacobsen SE (2004). Bone marrow-derived hematopoietic cells generate cardiomyocytes at a low frequency through cell fusion, but not transdifferentiation. Nat Med 10: 494-501.

38. Anderson DJ, Gage FH, Weissman IL (2001). Can stem cells cross lineage boundaries? Nat Med 7: 393-395.

39. Morshead CM, Benveniste P, Iscove NN, van der Kooy D (2002). Hematopoietic competence is a rare property of neural stem cells that may depend on genetic and epigenetic alterations. Nat Med 8: 268-273.

40. Ianus A, Holz GG, Theise ND, Hussain MA (2003). In vivo derivation of glucose-competent pancreatic endocrine cells from bone marrow without evidence of cell fusion. J Clin Invest 111: 843-850.

41. Choi JB, Uchino H, Azuma K, Iwashita N, Tanaka Y, Mochizuki H, Migita M, Shimada T, Kawamori R, Watada H (2003). Little evidence of transdifferentiation of bone marrow-derived cells into pancreatic beta cells. Diabetologia 46: 1366-1374.

42. Lechner A, Yang YG, Blacken RA, Wang L, Nolan AL, Habener JF (2004). No evidence for significant transdifferentiation of bone marrow into pancreatic betacells in vivo. Diabetes 53: 616-623.

43. Mathews V, Hanson PT, Ford E, Fujita J, Polonsky KS, Graubert TA (2004). Recruitment of bone marrow-de- 
rived endothelial cells to sites of pancreatic beta-cell injury. Diabetes 53: 91-98.

44. Taneera J, Rosengren A, Renstrom E, Nygren JM, Serup P, Rorsman P, Jacobsen SE (2006). Failure of transplanted bone marrow cells to adopt a pancreatic beta-cell fate. Diabetes 55: 290-296.

45. Hess D, Li L, Martin M, Sakano S, Hill D, Strutt B, Thyssen S, Gray DA, Bhatia M (2003). Bone marrowderived stem cells initiate pancreatic regeneration. Nat Biotechnol 21: 763-770.

46. Hasegawa Y, Ogihara T, Yamada T, Ishigaki Y, Imai J, Uno K, Gao J, Kaneko K, Ishihara H, Sasano H, Nakauchi H, Oka Y, Katagiri H (2007). Bone marrow (BM) transplantation promotes beta-cell regeneration after acute injury through BM cell mobilization. Endocrinology 148: 2006-2015.

47. Li FX, Zhu JW, Tessem JS, Beilke J, Varella-Garcia M,
Jensen J, Hogan CJ, DeGregori J (2003). The development of diabetes in E2f1/E2f2 mutant mice reveals important roles for bone marrow-derived cells in preventing islet cell loss. Proc Natl Acad Sci U S A 100: 12935-12940.

48. Than S, Ishida H, Inaba M, Fukuba Y, Seino Y, Adachi M, Imura H, Ikehara S (1992). Bone marrow transplantation as a strategy for treatment of non-insulin-dependent diabetes mellitus in KK-Ay mice. J Exp Med 176: 1233-1238.

49. Nakayama S, Uchida T, Choi JB, Fujitani Y, Ogihara T, Iwashita N, Azuma K, Mochizuki H, Hirose T, Kawamori R, Inoue M, Watada H (2009). Impact of whole body irradiation and vascular endothelial growth factor-A on increased beta cell mass after bone marrow transplantation in a mouse model of diabetes induced by streptozotocin. Diabetologia 52: 115-124. 